\title{
Constructions of Students as Clients or Partners in Knowledge Creation?
}

\author{
Birgit Schreiber \\ University of the Western Cape \\ Address correspondence to Birgit Schreiber, $\mathrm{PhD}$ \\ Director \\ Centre for Student Support Services, University of the Western Cape \\ P/Bag X 17, Bellville 7535 \\ South Africa \\ birgitdewes@gmail.com
}

\begin{abstract}
This study explored notions of 'the student' within the South African higher education context. Qualitative data from interviews with twenty-three executive and senior Student Affairs staff and practitioners were collected from three higher education institution in South Africa. The data were thematically analysed. The findings suggest that notions about students as 'disadvantaged' and 'needing support' as reflected in the South African policy documents is not congruent with the discourses in current Student Affairs in South Africa. Findings suggest that deficit discourses have been replaced by strengths based paradigms which construct the student in heterogeneous individualistic terms. Consumerist frameworks constructing the student as client have also emerged. The conceptual framework within which Student Affairs is embedded needs to reflect the changed discourse in Student Affairs practice in South Africa.
\end{abstract}

Keywords: Constructs, Diversity, Heterogeneous Student Population, Higher Education, Higher Education Policy, Massification, Students, Student Affairs, Underpreparedness

\section{Introduction}

Various discursive and normative communities within higher education, such as Student Affairs, construct students differently. This paper explores some of the discourses which implicitly and explicitly construct 'the student' within the broader emerging discourse in higher education. The national policies which guide the higher education domain in South Africa have been formative in shaping constructions about students. Research into Student Affairs discourses reveal two central themes, firstly, the construction of students as complex and heterogeneous, and secondly, the student as client. These themes are discussed in relation to notions inherent in higher education policy in South Africa, which are located in deficit discourses.

Student Affairs provides support, services and development to students, while engaging with academic and administrative staff on issues of policy and practice. Student Affairs is also about the "student experience" and the intra- and inter- 
personal relationship among students and the students' embeddedness within the university context (Pascarella \& Terenzini, 2005. Bernstein described the "official recontextualising field" and the "pedagogic recontextualising field" (Bernstein, 2000, p. 42) in exploring the socially constructed notions about students which exist in the learning environment in higher education. These two areas, together with a third, the social domain, constitute "key institutional domains of practice where the interplay of mediating factors in student experience takes place" (Lange, 2010, p. 46). Student Affairs straddles this pluralist intersection of the co-curricular and the curricula, of faculty and student (Case, 2007; Lange, 2010; King \& Baxter-Magolda, 1996; Kuh, Kinzie, Schuh \& Whitt, 2010; Pascarella \& Terenzini, 2005; Scott, Yeld, Hendry, 2007; Sennet, Finchilescu, Gibson \& Strauss, 2003).

\section{The South African higher education context}

The changed higher education landscape requires a re-examination of the explicit notions about students. The construction of the 'disadvantaged' student relies on notions of deficiency and otherness. The discourse surrounding students has been that of "underpreparedness" and foundation courses and first-year experiences are designed to "up skill" the first-year students who come from "disadvantaged" backgrounds (DoE, 1996, p. 12). While poor schooling is a reality, as is the relatively poor social and cultural capital which particularly first generation students bring to their higher educating experience, it is essential that Student Affairs review how it engages with the past legacy without entrapping itself in potentially outdated and unhelpful discourses about "disadvantaged" and "underprepared" students (Mgqwashu, 2009).

\section{Formative policies constructing students in relation to student affairs}

Hay and Marais (2004, p. 61) assert that South Africa has an educational challenge of "millions of school leavers who are not adequately prepared for higher education", mainly as a results of the injurious pre-1994 political context in South Africa. Graduation rates, while not a perfect measure of success ratei, reflect huge problems in the system, and the reasons for poor graduation performances are myriad and generally disputed (Letsaka \& Maile, 2008). Broadening access has meant that a wide range of students with diverse preparedness profiles, especially scholastic preparedness but also social, epistemological, financial and emotional challenges, have entered higher education (Botha, Brand, Cilliers, Davidow, de Jager \& Smith, 2005; Case, 2007; Davidowitz \& Schreiber, 2008; Malefo, 2000; Petersen, Louw \& Dumont, 2009; Scott et al., 2007; Sennet et al., 2003).

The National Commission on Higher Education's reference to students' "unprecedented need" for "support" created by "massification" (DoE, 1996, p. 12), implicitly positions students within a deficit construct. The policy suggests that students need to receive remedial-type and supportive interventions to mediate the "underpreparedness" (DoE, 1996, p. 12) and to address the "widespread deficiencies" of students (DoE, 1997, p. 22). 
The shift in the South African higher education system was not only away from a closed educational system, which was self-referential and insular, but also in terms of constructions about students which were constructed as passive, homogenous and obedient recipients (Struthers, 2005). The student population has changed to a heterogeneous population which has diverse needs and requires flexible support and development provisions.

\section{Goals of the study}

This study was part of a larger research which explored the scope, role and function of Student Affairs in South Africa. The goals of this study were to explore the explicitly and implicitly held notions about students, as reflected in policy documents and as reflected in interviews with senior and executive Student Affairs staff at three higher education institutions in South Africa. The research questions were purposefully broad in order to allow for themes to emerge and were formulated as follows:

1. What are the scope, role, and function of Student Affairs at the three universities?

2. What theoretical framework and underpinnings inform Student Affairs?

3. What is the Student Affairs position and structure within the institutions and beyond?

4. What is the DHET policy context within which Student Affairs functions?

\section{Method}

\section{Research design}

Qualitative content analysis was employed to extract and illuminate the constructs held by Student Affairs practitioners and staff about students. Grounded theory research methodology required that the research questions were intentionally open and general to allow for themes to emerge (Glaser \& Strauss, 1967; Strauss \& Corbin, 1998).

\section{Participants and setting}

Participants were twenty-three Deputy-Vice Chancellors $(n=3)$, Student Affairs executives $(n=4)$ and practitioners $(n=16)$ from three universities in the Western Cape, South Africa. The three institutions are medium size contact universities with student enrolment of 20000,26000 and 28000 students respectively. Two of the three institutions are the first universities in the country, while one institution is a Historically Disadvantaged Institution.

\section{Data Collection and Procedure}

Data were collected using semi-structured individual interviews which were recorded, transcribed and coded according to expected and emerging themes (Strauss \& Corbin, 1998). 


\section{Data analysis}

Data were thematically analysed using grounded theory approaches (Brown, Stevens, Troiano \& Schneider, 2002; Strauss \& Corbin, 1998). This entailed constructing emerging themes with axial coding into new clusters. These new clusters and subthemes were scaffolded and grouped according to meaningful newly-emerging themes (Strauss \& Corbin, 1998).

\section{Ethical considerations}

Approval for this study was obtained from ethics committees at all three institutions. Participants were assured of confidentiality, signed consent forms, were invited on a free and voluntary basis, without any enticement and were assured that they could withdraw at any stage without penalty. Trustworthiness of findings was improved by employing three techniques: 1) exploring negative cases, 2) sharing analysis with participants, 3) having a peer reviewer to validate process and findings (Brown et al., 2002).

\section{Results and Discussion}

The emerging themes are discussed below. Two core themes resulted: students constructed as complex and heterogeneous participants in the learning process, and students as clients. In the discussion below, the numbers in brackets indicate the percentage of participants from the total of twenty-three, who reflected this particular theme. Details about the participants are distorted so as to assure confidentiality.

\section{Theme 1: Students as heterogeneous complex individuals}

In discussing Student Affairs role and function within higher education, some participants (61\%) suggested that the function has shifted from reductionist notions of providing services and providing extra-curricular and non-academic activities to facilitating integrated and comprehensive development of students. This discursive shift suggests a move towards viewing the students as "complex beings" (female, director) which includes development in personal, social, and academic spheres and acknowledges the interrelationship of these facets. One participant (male, director) stated this clearly, saying "we see a student as a whole - holistically". This suggests that students are viewed in multi-dimensional terms, with personal, social, cultural and academic lives, each of which impact on the total gestalt.

The terms holistic and co-curricular were used, and although the meaning across participants seemed not entirely congruous, their use suggests a wider acknowledgement of the idea of the complex student, away from a narrow type towards the notion of multi-faceted and comprehensive range of Student Affairs support and development services. This is expressed in the following quote: "So now we do much broader development, development of many aspects of the person, development for life beyond varsity" (male, director) 
There has been a re-conceptualisation, albeit tacit, of student life as a continuous experience, where numerous facets impact on the students' academic life and university experience. The shift away from reductionist skills training of students towards more comprehensive understanding of student development is evident. On female manager reflected that 'I think there is a great consciousness about the individual character of a student. We see them as complex beings with personal, social and academic lives which are intertwined'. And a male director revealed similar thoughts, by saying 'we want to take into account the life cycle of a student at the institution, and we also want to look at the student holistically in terms of his or her student experience at the institution: in the classroom, out of the class, socially, just seeing the student in his entirety'.

The notion that students' subjective experiences and narratives are relevant emerges clearly. This mirrors the theoretical argument that "development is intertwined", resting on the assertion that cognitive development is predicated on personal and social development (Baxter-Magolda, 1999, p. 47; Bernstein, 2000). In other words, cognitive development is deeply related to the development of restructured personal internal constructs, which develop from the active engagement with a context. Academic meaning-making is linked to personal meaning-making which rests on social embeddedness of the student (Baxter-Magolda, 1999; Bernstein, 2000).

A sub-theme emerged on higher education climate, culture and practices and its role in the articulation to the students' personal and subjective experience. This is poignantly expressed in the rhetorical question of a male executive member, who said: 'students come with their own experiences, and how do you articulate their experiences and the university climate?'. The shift towards a student-centred approach is evident. As Lange (2010, p. xi) stressed, a pressing need exists to explore "the relationship between students' success and their experience of universities as academic and social spaces". This recently emerging focus on the system within which the students are embedded has enabled a more textured exploration of constructions around students and hence, making sense of successes in multidimensional terms (CHE, 2010; Howell, 2005; Scott et al., 2007; Soudien, 2008).

Participants revealed a move away from deficit models of explaining student functioning to employing contextualised and strength-based theories. The 'shift away from all kinds of deficit models' (female, director) is apparent:

For example the old model of looking at students as deficient - the psychopathology of students and psychologising every single problem - this to me is not very helpful. (female, director)

We are in the process of moving away from it towards an asset-based approach, where you are saying - yes, there may still be deficits, but instead of focussing on the deficits, we are now looking at what do they have despite the challenges that 
they face, so we work with their internal resources and supportive factors. (female, executive member)

This quote highlights the paradigmatic shift of re-constructing the student in resource based narratives. The construction of the 'disadvantaged' student relies, in part, on notions of deficiency and otherness which is considered as unhelpful in addressing student and higher education concerns. The shift towards internal resources' and 'supportive factors' is evident from the thematic analysis of the data.

These emerging voices reveal complex notions, away from a 'type' of student, perhaps described in absolute, monochromatic and deficient terms, towards the recognition that, through massification and other influences, students are a fluid heterogeneous group and complex individuals, with fluid identities and a range of needs and capabilities (Mgqwashu, 2009). Resourced based constructs are used to describe students and there is a growing recognition the importance to review higher education status quo in order to articulate it to the student, who has shifted to the centre of higher education student affairs.

\section{Theme 2: Students as clients}

Participants described their understanding of their work in terms of providing ' $a$ service' (female, manager) and 'making sure students are satisfied' (female, manager) and 'get what they came for' (male, manager), in terms of personal gain, 'improved employment chances' (male, executive member) and improved economic advantages, focussing on individualised successes. The idea that students are clients and consumers who choose the most attractive institution, which offers them the best chance at gainful employment after graduation, appears evident.

Over a third of participants (35\%) mentioned the importance of an incentive system in attracting the student, as client, reflecting consumerist notions. The following quotes illustrate this:

I think that we are part of a new neo-liberal frame. The issue of incentives and the issue of my marketability are about how much I can do to improve my CV and it is just all about the market. You get notions of 'okay I am doing this because it is going to make my CV look good'. (male, executive member)

You can also get a certificate which says you completed this kind of leadership course. Yes, it is like a second transcript, students like to get this confirmation; it's good for their CVs. (male, manager)

We are hoping that this programme, which at the moment stands outside of the formal curriculum, that the students will be able to use it in building their transcripts. There will be a confirmation on their transcript; that is what gets them interested. (female, director) 
Some participants (22\%) reflected on the tension of serving the common good and 'pandering' (male, executive member) to the market and related notions of individualised success. One male executive was explicit about the influence of neoliberal thinking and criticised the move towards the 'university facing the market': So the language of economics has fundamentally reconfigured all of our frameworks and all of our paradigms in a bad way. So when we talk about graduate attributes -there will be a whole range of capacities that we are thinking about amongst those attributes, but employability would be the chief one. This whole shift of the university to face the market is deeply problematic - which is what I think has happened. (male, executive)

The idea of the student-client is steeped in the commercial understanding of education. Bourdieu (1996) discussed the inherent contradictions inherent in university's functioning as gate-keepers and maintaining elites while providing opportunities to deconstruct the very notions within which it is embedded and which maintain it. This idea is further explored by Soudien (2012) who poses the argument of the university as simultaneously reproducing social constructs and systems, but also presenting opportunities for self-interrogation. The construction of the student as client promotes the iteration of social systems rather than the reconstruction of these in more just terms.

These data suggest that the neo-liberal economic-political influences have affected the discourse and conceptualisation of students and their relationship to higher education. The trend towards recasting higher education as a commercial commodity heralds a shift towards viewing the student as a client (Castells, 2001; Buroway, 2010; Kezar, 2004; Sidhu, 2006; Singh, Kenway \& Apple, 2005). The notion that the student takes part in higher education as a passive recipient of a service removes the inter-relationship and circularity of collaborative knowledge creation, which is part of constructivist notions that knowledge is created, relative and contextually embedded. The idea of the student as a client, positions the student as a passive recipient outside of the collaborative support and development process, which is central to Student Affairs practice (Baxter-Magolda, 1999; Kuh et al., 2010).

\section{Conclusion}

The prevalent theme emerging from this study is the construction of the student as complex and diverse individuals, at the centre of student affairs, to whom higher education needs to articulate. There is a growing recognition that notions steeped in 'disadvantaged' and deficit discourses are replaced by resource and strength based paradigms. This paradigmatic shift is reflected in the focus on a wide range of support and development provisions which are understood to underpin academic functioning. 
The second theme which emerged in this study revealed the discursive references to students within a consumerist framework. This suggests that students are viewed as clients, getting a service which enables gainful employment.

Student Affairs is engaged with not only the student and institutional goals, but has broader obligations toward the common good which creates tensions around the partnering of two value systems with different and, at times, contradictory and incompatible principles. There are inherent ambiguities in the provider-client relationship which is steeped in consumerist frameworks and serves commercial goals. Student Affairs needs to explicitly engage with these contradictions and position itself within a locally relevant framework. 


\section{References}

Baxter-Magolda, M. (1999). Constructing adult identities. Journal of College Student Development, 4O(6), p. 629-644.

Bernstein, B. (2000). Pedagogy, symbolic control, and identity: theory, research, critique. Rowman \& Littlefield.

Botha, HL., Brand, H., Cilliers, C., Davidow, A., de Jager, A. \& Smith, D. (2005). Student counselling and development services in higher education institutions in South Africa. South African Journal of Higher Education, 19(1), 73-88.

Bourdieu, P. (1996). The State Nobility: Elite schools in the field of power. Cambridge: Policy Press.

Brown, S.C., Stevens, R.A., Troiano, P.F. \& Schneider, M.K. (2002). Exploring complex phenomena: Grounded theory in student affairs research. Journal of College Student Development, 43(2), p. 1-11.

Buroway, M. (2010). Deliberative democracy in a global context: A South African model of higher education? Paper presented at Stakeholder Summit on Higher Education Transformation, Cape Peninsula University of Technology, Cape Town, South Africa.

Case, J. (2007). Alienation and engagement: Exploring students' experiences of studying engineering. Teaching in Higher Education, 12(1), p. 119-133.

Castells. M. (2001). Challenges of globalization: South African debates with Manuel Castells, Cape Town, RSA, Maskew Miller Longman.

CHE (Council on Higher Education) 2010. Higher Education Monitor 10. Retrieved from, http://www.che.ac.za/heinsa/tl/participants/ on 19 January 2012.

Davidowitz, B. \& Schreiber, B. (2008). Facilitating adjustment to higher education: Towards enhancing academic functioning in an academic development programme. South African Journal of Higher Education, 22(1), 191-206.

DoE (Department of Education) 1996. National Commission on Higher Education: An overview of a new policy framework for higher education transformation. Pretoria, RSA, Department of Education.

DoE (Department of Education) 1997. White Paper: Programme for the transformation of higher education. Government Gazette No. 18207, 15 August 1997. Pretoria, RSA, Government Press.

Hay, H. R. \& Marais, F. (2004). Bridging programmes: Gain, pain or all in vain. South African Journal of Higher Education, 18(2), 59-75.

Howell, C. (2005). Higher Education Monitor No 3: South African Higher Education Responses to Students with Disabilities. Council on Higher Education, Pretoria, RSA, Council on Higher Education (CHE).

Kezar, A. (2004). Obtaining integrity? Reviewing and examining the charter between higher education and society. The Review of Higher Education, 27(4), p. 429459.

King, P. \& Baxter-Magolda, M. (1996). A developmental perspective on learning. Journal of College Student Development, 37(2), p. 163-173.

Kuh, G. Kinzie, J., Schuh, J. \& Whitt, E. (2010). Student success in college. San Francisco, CA, Jossey-Bass. 
Lange, L. (2010). Access and throughput in South African higher education: Three case studies. From http://www.che.ac.za/documents/dooo206/HigherEducationMonitorg.pdf retrieved on 11 November 2011.

Letseka, M. \& Maile, S. (2008). High university drop-out rates: A threat to South Africa's future. Policy Brief, Human Science Research Council South Africa, Pretoria, RSA: HSRC.

Malefo, V. (2000). Psycho-social factors and academic performance among African women students at a predominantly white university in South Africa. South African Journal of Psychology, 30(4), 40-45.

Mgqwashu, E.M. (2009). Re-visiting, re-thinking, and re-naming 'educational disadvantage' in higher education. South African Journal of Higher Education, 23(4), p. 722-738.

Pascarella, E. \& Terenzini, P. (2005). How college affects students: A third decade of research (Vol 2). San Francisco, CA, Jossey-Bass.

Petersen, I., Louw, J., \& Dumont, K. (2009). Adjustment to university and academic performance among disadvantaged students in South Africa. Educational Psychology, 29(1), 99-115.

Scott, I., Yeld, N. \& Hendry, J. (2007). Higher Education Monitor No 6: A case for improving teaching and learning in higher education in South Africa. Pretoria, RSA, Council on Higher Education (CHE).

Sennett, J., Finchilescu, G., Gibson, K. \& Strauss, R. (2003). Adjustment of black students at a historically white South African university. Educational Psychology, 23(1), p. 107-116.

Sidhu, R. (2006). Universities and globalization: To market, to market. Mahwah, NJ, Lawrence Erlbaum Associates.

Singh, M., Kenway, J. \& Apple, M. (2005). Globalizing education: Perspectives from above and below. In M. Apple, J. Kenway \& M. Singh (eds), Globalizing Education. New York, NY, Peter Lang.

Soudien, C. (2008). Report on transformation and social cohesion and the elimination of discrimination in public higher education. Pretoria, RSA, Council on Higher Education (CHE).

Soudien, C. (2012). The promise of the university: what it's become and where it could go. In B. Leibowitz (ed), Higher Education for the Public Good: Views from the South. Sun Media, Stellenbosch, South Africa.

Strauss, A. \& Corbin, J. (1998). Basics of qualitative research: Techniques and procedures for developing grounded theory (2nd. ed.). Thousand Oaks, CA, Sage.

Struthers, P. (2005). The role of occupational therapy, physiotherapy and speech and language therapy in education support services in South Africa. PhD Dissertation, University of the Western Cape, South Africa.

Tshiwula, L. (2011). Resilience in a higher education institution. Paper presented at the $13^{\text {th }}$ Annual SAASAP Conference, 19-21 October 2011, Cape Town, South Africa. 


\begin{abstract}
${ }^{\mathrm{i}}$ Using graduation rates as indicators of success fails to recognise that student progression through the system is not linear, nor that students transfer to other institutions and that a premature drop out is potentially not a 'failure' in terms of human capital development (Wits, 2006, in CHE, 2010).
\end{abstract}

